Teologia i Moralność, volumen 16(2021), numer 1(29)

doi: 10.14746/TIM.2021.29.1.1

ORCID: 0000-0001-7470-1473

AGNIESZKA CYBAL-MICHALSKA

Uniwersytet im. Adama Mickiewicza w Poznaniu

Wydział Studiów Edukacyjnych

\title{
Myśl edukacyjna - o powadze teoretyczności ustaleń socjopedagogicznych
}

Nie teoria jest dobrem, ale dobra teoria

Rzeczywistość społeczno-kulturowa, poddawana nieustannym procesom zmiany, prowadzi do wielokontekstowych przemian społecznych wyrażających się w permanentnej kreacji współczesnego społeczeństwa, któremu kształt nadały dwa procesy: modernizacji i globalizacji ${ }^{1}$. Wielowymiarowość i złożoność współczesnej konfiguracji społecznej przyczynia się do trudności w uchwyceniu i jednoznacznym dookreśleniu czynników determinujących zmiany w systemie społecznym oraz teoretycznym opisie społecznego wymiaru bytu ludzkiego, co nie pozostaje bez znaczenia dla procesu budowania teorii - wiedzy teoretycznej wyjaśniającej procesy społeczno-kulturowe i socjopedagogiczne.

$\mathrm{Na}$ wstępie podjętej narracji należy wyraźnie zaakcentować cel podjętego wywodu. W niniejszym artykule uwaga będzie skupiona na charakterystyce rysów społeczno-kulturowych globalizującego się świata, co ma posłużyć zobrazowaniu współczesnej kultury w celu zaakcentowania istoty i powagi poziomu poznania (zjawisk społecznych) na drodze przyjęcia wybranej teorii dla ich rozpoznania, a następnie odniesienia się do osobliwości myślenia pedagogicznego, czyli do powinności uprawiania naukowej (teoretycznej) pedagogiki.

${ }^{1}$ Na jakościową zmianę społeczeństwa globalnego wywołaną przez wyróżnione procesy wskazuje P. Sztompka. Dla autora stanowią one ważką płaszczyznę analitycznego dyskursu nad jakością nowoczesności, wielością nowoczesności i późną nowoczesnością (Sztompka 2002, 557-578). 


\section{Społeczno-kulturowy wymiar globalizacji jako punkt odniesienia do przyjęcia określonej teorii społecznej wyznaczającej jakość jej opisu i eksplantacji}

Problematyka globalizacji jako opisu wspólnego mianownika dla swoistości zachodzących $\mathrm{w}$ świecie procesów znajduje się w polu zainteresowań różnych dyscyplin naukowych (filozofii, socjologii, politologii, kulturoznawstwa, pedagogiki, ekonomii) od niedawna, nie ma więc utrwalonej i bogatej tradycji. Pierwszym artykułem socjologicznym, w którego tytule pojawiło się pojęcie „globalizacja”, był tekst Rolanda Robertsona (1985), zatytułowany The Relativization of Societies: Modern Religion and Globalization (Robertson 1985). Dopiero w latach dziewięćdziesiątych zauważamy - jak ujmuje to Malcolm Waters - ,globalizację posługiwania się tym pojęciem, które staje się wszechobecne" i może stanowić podstawową kategorię humanistycznego dyskursu, a jako termin mniej kontrowersyjny zastępuje pojęcie „postmodernizm” na określenie przemian współczesnego świata (Kempny 1998, 242; Cybal-Michalska 2006, 19).

Punktem wyjścia rozważań nad szerokim spektrum omawianego zagadnienia jest uznanie globalizacji za zjawisko. W tym ujęciu globalizacja rozumiana jest jako fakt, który „da się zaobserwować, postrzec zmysłami [...], jako coś wyjątkowego” (Wierzbicka 1998, 655), „występującego w jakiejś dziedzinie" (Sobol 2000, 1275) bądź dziedzinach. Rozważanie globalizacji jedynie jako procesu, a więc ,przebiegu powiązanych przyczynowo, następujących po sobie zmian stanowiących stadia rozwoju, przeobrażania się czegoś" (Wierzbicka 1998, 148), tylko częściowo owo zjawisko przybliża. Immanentną cechą rozważań nad globalizacją jest również zwrócenie uwagi na strukturę oraz funkcję, jaką pełni to zjawisko. W analizach wielu autorów będzie więc można dostrzec jakościowe zróżnicowanie podejść do globalizacji, w ujęciu procesualnym, strukturalnym i funkcjonalnym, interpretowanej jako zjawisko odgrywające określone role, wnoszące swój wkład w obraz złożoności współczesnego świata. Ponadto, jak podkreśla R. Robertson, różnorodność „odpowiedzi” na globalizację wywiera wpływ na jakość, kierunek i rezultat tego procesu, co pozwala wnioskować, że kształt „pola globalnego” jest w znacznym stopniu „zależny od nas samych” (Robertson 1992, 161; Cybal-Michalska 2006, 20).

Globalizacja według Martina Albrowa „odnosi się do tych wszystkich problemów, w wyniku których narody świata zostają włączone w jedno światowe społeczeństwo, społeczeństwo globalne" (Kempny 1998, 241). Kierunek podobnie rozumianych przemian, które obejmują swym zasięgiem cały glob, ilustruje R. Robertson, twierdząc, że globalizacja to „zespół procesów, które tworzą jeden wspólny świat” (Kempny 1998, 241). Stanowisko R. Robertsona, określone mianem „teorii woluntarystycznej”, opiera się na przekonaniu, 
że zarówno jednostki, społeczeństwa, „systemy” społeczeństw, jak i całą ludzkość należy traktować jako jeden, spójny szkielet analityczny. Równie ważną kwestią, w tym aspekcie, jest unikanie redukcjonizmu, z jego jawnie funkcjonalistycznymi, utylitarnymi i materialistycznymi formami. „Pole globalne”, jako całość, jest społeczno-kulturowym ,systemem”, który z jednej strony jest wynikiem „kompresji świata”, ale z drugiej strony - usamodzielnia kultury, cywilizacje, grupy etniczne, społeczeństwa narodowe, „intra-” i „cross-” narodowe ruchy i organizacje (Robertson 1992, 61). Procesy sprzężone ze zjawiskiem globalizacji są często traktowane jako dyfuzje wzorów kulturowych i nazywane westernizacją, macdonaldyzacją (G. Ritzer) czy amerykanizacją, co eksponują w swoich analizach Hans-Peter Martin i Harald Schumann, pisząc, że „Ameryka wprawdzie nie jest wszystkim, ale bez Ameryki wszystko było dotąd niczym" (Martin, Schumann 1990, 258). Marian Golka dodaje, że współcześnie „świat ogląda mityczną Amerykę, a Ameryka pokazuje zmitologizowany, spreparowany świat" (Golka 1999, 136) przyczyniający się do rozwoju szeroko rozumianej konsumpcji. Przedstawione poglądy łączy próba zdefiniowania globalizacji jako zjawiska bądź procesu zmierzającego do stworzenia jednorodnego świata i jednego wspólnego społeczeństwa - społeczeństwa światowego. $Z$ perspektywy omówionego podejścia wszelkie przemiany współczesnego świata ujmowane są jako wpływy kulturowe bądź cywilizacyjne, obejmujące obszar całego globu. Trudno w sposób jednoznaczny odpowiedzieć na pytanie, czy globalizacja jest po prostu procesem homogenizacji, jako że siły fragmentacji i hybrydyzacji są w równym stopniu silne. Bardziej przekonująca jest interpretacja globalizacji podkreślająca jej heterogeniczny charakter (Barker 1999, 38-39; Cybal-Michalska 2006, 20-21).

$\mathrm{Z}$ opozycji wobec konwencjonalnych teorii społecznej modernizacji (a w szczególności ich „zachodniocentryzmu”) i braku zainteresowania cywilizacyjną i kulturową różnorodnością narodziła się perspektywa ujmowania świata jako całości, ewoluującego w ,globalnie” sugerowanych kierunkach. Globalizacja, zdaniem M. Golki, nie stworzyła świata w postaci homogenicznej i nie wiadomo, czy kiedykolwiek dojdzie do urzeczywistnienia tej wizji. Echo tej opinii można odnaleźć w wypowiedzi Mike’a Featherstone’a, który twierdzi, że aktualny proces globalizacji, sprzeczny z wcześniejszymi oczekiwaniami na coraz bardziej homogeniczny świat, ,prowadzi do coraz większej wrażliwości na różnice”, jest konsekwencją faktu, iż „przepływy informacji, wiedzy, pieniędzy, towarów, ludzi i wyobrażeń wzmogły się do tego stopnia, że poczucie przestrzennych odległości, które oddzielały i izolowały ludzi od potrzeby brania pod uwagę wszystkich innych podmiotów życia społecznego tworzących ludzkość uległy zniszczeniu”. W efekcie „wszyscy znajdujemy się na podwórku innych" (Kahn 1995, 126-128). Globalizacja, jako zjawisko wyrastające z procesu różnicowania się i pluralizmu kulturowego współczesnego 
świata, sytuuje się w kontekście rozważań Luisa Ronigera. Zdaniem autora, globalizacja to „zarówno dyfuzja określonych modeli ekonomicznego rozwoju, wzrostu, urynkowienia, jak i odpowiadająca temu procesowi adaptacja lub odrzucenie kulturowych wzorów westernizacji” (Starosta 2000, 48). W tym kontekście globalizacja winna być raczej rozumiana jako światowa sieć współzależności, oddziałująca na poszczególne społeczeństwa i państwa, tak że stanowią one części pewnej całości (Golka 2001, 79). Najbardziej znani przedstawiciele omawianego podejścia: Anthony Giddens, Anthony McGrew i Paul P. Streeten, argumentują, że globalizacja ujmowana jako współzależność, oddziaływanie, intensyfikacja stosunków między państwami jest wyrazem postrzegania świata jako sieci powiązań i tylko w tym kontekście można traktować globalizację całościowo i wskazywać na jej cywilizacyjne implikacje. U podstaw rozważań A. Giddensa leży założenie, iż ,globalizacja to intensyfikacja stosunków społecznych o światowym zasięgu, która łączy różne lokalności w taki sposób, że lokalne wydarzenia kształtowane są przez zdarzenia zachodzące w odległości wielu tysięcy mil i same na nie oddziałują" (Kempny 1998, 242). Uściślając zakres tego pojęcia, należy uznać za A. McGrewem, że globalizacja „polega na wielości powiązań i wzajemności oddziaływań państw i społeczeństw tworzących obecny światowy system" (Golka 1999, 114). W konsekwencji, jak podkreśla Luis Roniger, globalizacja charakteryzuje się: „transnacjonalizacją wzorów kulturowych, kontynentalizacją wymian ekonomicznych, regionalną transnacjonalizacją oraz wzrostem znaczenia lokalności" (Starosta 2000, 48). Na aspekt pogłębiania się światowych powiązań niemal we wszystkich sferach współczesnego życia społeczno-kulturowego, ekonomicznego, politycznego, zwraca również uwagę Paul P. Streeten, definiując globalizację jako ,intensyfikację ekonomicznych, politycznych i kulturowych stosunków poprzez granice" (Liberska 2002, 17; Cybal-Michalska 2006, 22).

U źródeł powyższych stwierdzeń nie leży rozstrzygnięcie, czy pojęcie globalizacji odnosi się do dotyczących całego świata następstw czy przedsięwzięć. Odpowiedzi na to pytanie udziela Zygmunt Bauman, podkreślając, iż wszechobecny termin globalizacja najczęściej odnoszony jest do powszechnych skutków, „ciągle niezamierzonych i nieprzewidzianych”, a nie inicjatyw i przedsięwzięć. Konsekwencją wymienionego poglądu jest uznanie globalizacji współczesnego świata, którego los zależy w dużej mierze od przypadku na płaszczyźnie globalnych działań, zależności i interesów, za proces $\mathrm{w}$ dużym stopniu niekontrolowany, spontaniczny, a także nieodwracalny; co więcej, trudno jest jednocześnie określić jego stan. Perspektywy oglądu globalizującego się świata są więc trudne do uchwycenia ze względu na dynamiczny charakter i trwanie omawianego procesu. Pogląd ten znajduje współczesne potwierdzenie w rozważaniach Z. Baumana, zgodnie z którym ,pojęcie globalizacji przekazuje nieokreślony, kapryśny i autonomiczny charakter świa- 
ta i jego spraw, brak centrum, brak pulpitu operatora, zespołu dyrektorów, biura zarządu. Globalizacja jest inną nazwą «nowego nieporządku świata»" (Bauman 2000, 71) i „odnosi się bezpośrednio do «anonimowych sił» G.H. von Wrighta; sił działających w pustce, na mglistej, grząskiej, nie dającej się oswoić ani przebyć «ziemi niczyjej», rozciągającej się poza zasięgiem możliwości konkretnego planowania i działania kogokolwiek" (Bauman 2000, 72-73; Cybal-Michalska 2006, 23). Zakres problemowy terminu „globalizacja” ma charakter historyczno-społecznej konstrukcji uwzględniającej dynamikę czasową wielu procesów społeczno-kulturowych i cywilizacyjnych składających się na obraz współczesnego świata, co wskazuje na relatywną nowość pojęcia globalizacji.

\section{Praktyka poznawcza w naukach społecznych i oczekiwania wobec wa- lorów eksplanacyjnych twierdzeń}

Przywołane powyżej rozstrzygnięcia uświadamiają, że na szczególną uwagę zasługuje wymiar czasu (nieprzewidywalna zmienność tempa zmian rzeczywistości społeczno-kulturowej) oraz wymiar przestrzeni (zróżnicowanie zakresu zmian, jakim podlegają różne społeczeństwa) (Misztal 2000, 157). Stricte socjologiczny dyskurs odwołuje się do najbardziej ogólnego poziomu poznania wiążącego się z przyjęciem określonej teorii czy też filozofii ${ }^{2}$ społecznej wyznaczającej jakość poznania, opisu, diagnozy, eksplanacji i możliwości rozumienia otaczającej rzeczywistości (Cybal-Michalska 2013, 119).

Praktyka poznawcza i oczekiwania wobec walorów eksplanacyjnych twierdzeń (ich trafności) przez teorię formułowanych (przy refleksji nad jej zdolnością eksplanacyjną w ogóle) odwołują się do możliwości teoretycznego uogólnienia i klasyfikowania świata społecznego czy też przekładania tez teoretycznych na grunt poznania empirycznego w celu ich weryfikacji, jak również wyjaśniania zjawisk poprzez identyfikację mechanizmów przyczynowych i procesów ujawnianych poprzez jakość swoich efektów (Scott i Marshall 2009, 761). I chociaż teoria socjologiczna, ,jako praktyka i jako instrument poznania rzeczywistości społecznej podlega zewnętrznej krytyce co do stopnia, w jakim spełnia ona uniwersalne kryteria naukowe, i jednocześnie jest przedmiotem autoocen, które wskazują na pozytywne lub potencjalnie rozwojowe aspekty jej autonomicznego statusu poznawczego" (Misztal 2000, 173), to jednak jej walor kognitywny stanowi formę przedstawienia struktury rze-

\footnotetext{
${ }^{2}$ Zdaniem G. Marshalla, termin „,filozofia społeczna” bywa odnoszony do doniosłych „pomysłów" teoretycznych - do najbardziej ogólnego poziomu teorii społecznych, takich jak: funkcjonalizm strukturalny, fenomenologia, czy marksizm (Marshall 2005, 384).
} 
czywistości społecznej wykraczającej poza możliwości bezpośredniego zaobserwowania czy zmierzenia.

W tym sensie istotne wydaje się określenie granic pola poznawczego pozwalających na dookreślenie, czy teoria ujmuje „«całość», «większość»», oraz «najważniejszą część» [...] zakresu zmienności determinant czy komponentów eksplanandum" (Misztal 2000, 181)3 ${ }^{3}$ a więc przedmiotu poznania (rozumianego jako to „coś”, co należy wyjaśnić), który ma zostać wyjaśniony. Zdolność eksplanacyjną teorii określa się przez rozpoznanie wielkości zakresu rzeczywistości, do którego teoria ma zastosowanie, przeto jest ona „pochodną praktyk interrogacyjnych wprzęgniętych w proces poznawczy i zależy od tego [...] czy uwzględniają czynniki porównawcze, historyczne i teoretyczne" (Misztal 2000, 183). Zasadnicze znaczenie ma status poznawczy teorii, która pozwoliłaby na zrozumienie zjawiska przyspieszenia historycznego i ,triumfującej współczesności” (P. Sztompka). Makrospołeczne procesy determinujące znaczące przekształcenia współczesnego globalizującego się społeczeństwa w ciągu ostatnich lat nabrały nowej jakości i stały się nieodwracalną tendencją rozwojową. Nowe procesy różnicowania, wielowymiarowości i współzależności różnych dziedzin życia społecznego oraz kulturowej pluralizacji współczesnego świata wpływają na praktykę kognitywną, skłaniającą do uwzględnienia „W dyskursywny sposób «zmienną naturę życia społecznego na całym świecie»” (Misztal 2000, 186). Fakt ten aktualizuje problem ,ateoretyczności wielu ustaleń socjologicznych" (Manterys, Mucha 2009, VII) i kumulacji wiedzy społecznej kodyfikowanej w ramach wyróżnionych paradygmatów. W obliczu dynamiki rozwoju i trudnego do przewidzenia kierunku zmiany społecznej może pojawić się, na co wskazuje Raymond Baudon, tendencja „do doraźności praktyk interogacyjnych i do udzielania odpowiedzi ad hoc na pytania o zależności między rozmaitymi elementami rzeczywistości społecznej. [...] «Dobra teoria [...] ma zdolność eksplanacyjną, która obejmuje szereg istotnych faktów, łącznie z faktami jeszcze nieznanymi»" (Misztal 2000, 189-190). Logika zmiany konfiguracji organizacyjnej społeczeństwa nie jest łatwa do uchwycenia. Wiele orientacji teoretycznych podlega dewaluacji. Poddane krytycznemu oglądowi ukazującemu ich ograniczenia ukierunkowują myślenie na ,potrzebę wypracowania nowych instrumentów analitycznych" (Manterys, Mucha 2009, VII) odnoszących się do jakości współczesnego społeczeństwa w dynamicznym procesie zmiany. Globalizacyjne tendencje

\footnotetext{
${ }^{3}$ Autor podkreśla, iż teoria może być satysfakcjonująca zarówno wtedy, gdy obejmuje „większość” determinant eksplanadum, jak również wówczas gdy koncentruje się na „mniejszej jego części” przy założeniu jednak, że dysponuje „takim istotnym rozpoznaniem pola zmienności, które pozwala na stwierdzenie, że komponenty, które są przedmiotem praktyki poznawczej, są faktycznie bardziej doniosłe heurystycznie" (tamże, s. 182) aniżeli te pominięte - mniej istotne dla wyjaśnienia obranego fragmentu rzeczywistości społecznej.
} 
świata implikują „heterogeniczność dialogów” (A. Appardurai). Potrzebna jest refleksja nad rodzajem teorii, która najlepiej posłuży eksploracji zjawisk społecznych. W świetle poczynionych rozważań konstytutywną cechą „,dobrej” teorii jest jej dyskursywny charakter, „otwarcie na zjawiska i procesy jeszcze nieznane, dopuszczenie dialogu teoretycznego oraz [...] pryncypialne dopuszczenie założenia o historycznej zmienności własnej zdolności eksplanacyjnej" (Misztal 2000, 189-190). To, co stanowi istotę współczesnego „teoretyzowania” (J.C. Alexander), nie ogranicza się li tylko do debaty wokół teorii ogólnej. Dynamikę rozwoju współczesnej aktywności teoretycznej charakteryzuje nie tylko wysoka kultura filozoficzna i metodologiczna, ale także możliwość zastosowania poczynionych ustaleń w wyodrębnionych subdyscyplinach socjologii (Manterys, Mucha 2009, VIII-IX). Podczas prób dookreślania powyższych rozważań nad istotą teoretyzowania socjologicznego i jego „płodnością” pojawia się problem rozumienia „teorii naukowej”. Obszerna debata naukowa poświęcona temu zagadnieniu pozwala na przyjęcie rozumienia teorii jako ,systemu dedukcyjnego, z jasno określonym zbiorem założeń i abstrakcyjnych twierdzeń podstawowych o najwyższym stopniu ogólności (najlepiej aksjomatów) z których wyprowadza się twierdzenia niższego rzędu" (Manterys, Mucha 2009, XIII). Aksjomaty, nierzadko w teoriach socjologicznych niesformułowane wprost, to postulaty, założenia, uznawane powszechnie zasady traktowane jak oczywiste prawdy (Scott, Marshall 2009, 33). Ogólne, zdefiniowane przez Stefana Nowaka, określenie terminu „teoria” akcentuje, że jest to „zespół praw (twierdzeń) uporządkowany tak, aby stanowiły one pewną wewnętrznie spójną konstrukcję logiczną" (Ziółkowski 2006, 16). Teoria wyjaśnia i interpretuje zjawiska, „starając się dotrzeć do możliwie uniwersalnej istoty mechanizmów kierujących społecznymi procesami i podtrzymywaniem oraz dynamiką struktur" (Manterys, Mucha 2009, XIII), co dodatkowo aktualizuje potrzeba nowego spojrzenia na strukturę społeczną. Nawet przy Mertonowskim postulacie budowy teorii średniego zasięgu ${ }^{4}$, ilustrującym dążenie do teoretycznego ujęcia wybranych aspektów i przejawów życia społecznego, teorie ,powinny być oparte na pojęciowych modelach rzeczywistości społecznej, a więc pewnych ogólnych powiązanych wzajemnie hipotezach dotyczących tego, jakie jej cechy i jakie związki między tymi cechami są uważane za szczególnie istotne" (Manterys, Mucha 2009, XIII), co również stwarza możliwości antycypowania kierunku i zakresu zjawisk społecznych. Zdefiniowa-

\footnotetext{
${ }^{4}$ Ten wybitny amerykański socjolog, autor pracy zatytułowanej Social Theory and Social Structure (1957, wyd. pol. 1982), teorię średniego zasięgu definiuje jako: „teorie które się znajdują pomiędzy niezbyt doniosłymi, ale koniecznymi hipotezami roboczymi powstającymi w nadmiarze w toku codziennej pracy badawczej i najogólniejszymi konsekwentnymi próbami rozwinięcia jednolitej teorii, dzięki której można byłoby wyjaśnić prawidłowości widoczne w zachowaniach organizacji oraz zmianie społecznej” (Marshall 2005, 393).
} 
nie istoty teorii, zaproponowane przez Jerzego Szackiego, uwzględnia świadomość nieistnienia takiej, która spełniałaby wszystkie warunki. W ujęciu autora teorią ,jest wszelki zespół pojęć i stosunkowo ogólnych twierdzeń o rzeczywistości społecznej mający porządkować dostępną wiedzę na jej temat oraz dostarczać wytycznych dla dalszych obserwacji i badań" (Ziółkowski 2006, 17; Cybal-Michalska 2013, 14-16).

W świetle charakterystycznego na nauk społecznych dyskursu nad ekspansywnym charakterem rozwoju społecznego ,odżywa spojrzenie na społeczeństwo i kulturę w kategoriach długiego trwania, zmiany dostrzegalnej poprzez uruchomienie wyobraźni historycznej, poszukiwania długofalowych trendów i ich związków z przemianami na poziomie życia codziennego" (Manterys, Mucha 2009, XIII). Wyłania się nowe spojrzenie na „nowoczesną formację społeczną" (Sztompka) sprzyjające skoncentrowaniu narracji na naturę świata społecznego - wzajemną zależność między globalnością (nową jakością stosunków społeczno-kulturowych na skalę globu) a indywidualnymi dyspozycjami jednostek. Intelektualiści odwołują się do wybranej teorii rozwoju społecznego i interpretacji zmiany społecznej, ze szczególnym uwzględnieniem sfer życia społecznego, stanowiących impuls przemian dokonujących się w społeczeństwie.

Wyzwania współczesności, szeroki kontekst procesów powiązanych ze zjawiskami modernizacji i globalizacji, skłaniają do poszukiwania perspektywy teoretycznej, która pozwoli na możliwie najlepsze i wnikliwe rozpoznanie zjawisk społecznych. Refleksja nad „ateoretycznością” wielu orientacji teoretycznych prowokuje, inspiruje, skłania i aktualizuje praktykę namysłu i poszukiwania nowych rozwiązań teoretycznych. W rezultacie dotychczasowe pomysły teoretyczne poddane dogłębnej krytycznej recepcji „ukazującej jej ograniczenia, stają się przedmiotem analitycznej obróbki, punktem wyjścia nowych rozwiązań teoretycznych" (Manterys, Mucha 2009, VII), próbą przełamania biegunowo odmiennych stanowisk ${ }^{5}$, po to by - jak podkreśla Steven Seidman - „zmierzyć się z wyzwaniami, które konstytuuje [...] kryzys społeczeństwa zachodniego, związany z zakwestionowaniem nowoczesnego projektu społeczeństwa" (Manterys, Mucha 2009, VIII; Cybal-Michalska 2013, 17-18).

${ }^{5}$ M. Ziółkowski mówi wręcz o unieważnieniu przeciwstawności stanowiska krańcowych, a w szczególności między: „holizmem a indywidualizmem, między determinizmem a aktywizmem, a [...] na poziomie metateoretycznym - między obiektywizmem a subiektywizmem w poznaniu, oraz między wartościowaniem a wolnością od wartościowania w naukach społecznych" (Ziółkowski 2006, 631. To poszukiwanie równowagi między „ujęciami makrosocjologicznymi, obiektywistycznymi i deterministycznymi z jednej strony a ujęciami mikrosocjologicznymi, indywidualistycznymi, i subiektywnymi z drugiej (tamże). 


\section{Refleksja nad teoriopoznawczym podejściem służącym wyjaśnieniu szerokiego spektrum procesów socjopedagogicznych}

Podczas rozważań nad istotą teoretyzowania i jego „płodnością” pojawia się - świadcząca o jakości postawionego tematu - refleksja, pytanie: o możliwe teoriopoznawcze podejście służące wyjaśnieniu szerokiego spektrum procesów wychowawczych czy szerzej - edukacyjnych. Pedagog w swojej aktywności teoretyzowania poszukuje odpowiedzi nie tylko na pytanie świadczące o socjologicznym punkcie widzenia, a mianowicie: Jaka teoria podejmie się wyjaśnienia szerokiego spektrum procesów odpowiadających za „organizowanie różnorodności” w obrębie zglobalizowanego społeczeństwa płynnonowoczesnego, w której partycypuje podmiot?, ale również na pytanie: Jaka jest podatność struktur społecznych na wpływy edukacyjne? To w istocie troska o świadomość miejsca i funkcji edukacji w ładzie społecznym, o możliwość kreowania ulepszających składowych dotychczasowego systemu społecznego. Można z całą pewnością, za Tadeuszem Lewowickim przyjąć, że „pedagogika jest nauką, od której spodziewać się można pozytywnego wpływu na praktykę życia społecznego. Udział pedagogów akademickich w społecznym ruchu na rzecz zmiany praktyki oświatowej spostrzegać należy jako powinność i jako ważny czynnik przeobrażeń edukacji. [...] Silne więzi teorii pedagogicznej i oświatowej praktyki umożliwiają nie tylko formułowanie uogólnień w postaci idei, koncepcji i teorii - znaczących w rozwoju dyscypliny. Dadzą także możliwość przenoszenia tych idei i koncepcji na grunt praktyki. A stanie się to osiągalne - bez zniekształceń, wynaturzeń, powierzchowności - przy zaangażowaniu pedagogów akademickich praktyki”" (Lewowicki 2004, 48-50). Jakże pouczająco brzmi konstatacja Zbigniewa Kwiecińskiego, że pedagogika „zawiera $\mathrm{w}$ sobie zarówno teorie i badania tworzące wiedzę dla wiedzy oraz generujące wiedzę o kształceniu, wychowaniu i oświacie, jak i wiedzę dla wiedzy [...] i dla zwykłych praktyków edukacji, a także «generalizację» o działaniu, to jest zwerbalizowane wersje (opisowe, a częściej normatywne) samych tych działań" (Kwieciński 2004, 29).

Niepodobna zaprzeczyć, że dla praktyki życia społecznego i tworzenia dla niej nowych prorozwojowych szans na uwagę zasługuje społeczna rola i użyteczność nauk pedagogicznych. Tym samym dynamika rozwoju ,pedagogicznego" teoretyzowania, której pedagog akademicki nie może zlekceważyć, powinna wyrastać z wysokiej kultury metodologicznej i uwzględniać możliwość zastosowania poczynionych ustaleń w subdyscyplinach pedagogiki. Trzeba przy tym podkreślić - na co uwrażliwia Bogusław Śliwerski, przywołując opinię Andrzeja Michała de Tchorzewskiego - że pedagogika teoretyczna czuwająca nad kulturą metodologiczną, poprawnością ontologiczną i epistemologiczną pozwoli subdyscyplinom pedagogicznym „w budowaniu przez nie 
«[...] zbioru zdań empirycznych, które wyjaśniają za pomocą praw i hipotez, definicji i twierdzeń oraz sądów klasyfikujących różnorodne fakty, zdarzenia i procesy należące do określonego przez nie przedmiotu poznania. Spełni ona sama w ten sposób swoją funkcję eksplanacyjną oraz heurystyczną»" (Śliwerski 2017, 74). W gruncie rzeczy mowa tu o koncentracji na konstruowaniu - jak ujmuje to przywołany przez Heliodora Muszyńskiego - David Kaplan - ,szerokiej i systematycznej struktury teoretycznej”, to znaczy systemu ściśle powiązanych, hierarchicznie uporządkowanych i logicznie zamkniętych twierdzeń teoretycznych" (Muszyński 2004, 89). I nie ulega zaiste wątpliwości, że trwanie w tym procesie to kierunek wysoce pożądany dla pedagogiki jako nauki w obszarze nauk społecznych i humanistycznych. Odpowiedzialna debata naukowa poświęcona zagadnieniu budowania teoretycznego charakteru pedagogiki, nieaspirująca bynajmniej do jednoznaczności w określeniu definicyjnego credo pojęcia „teoria pedagogiczna”, „teoria edukacji” pozwala na przyjęcie rozumienia teorii: jako ,systemu dedukcyjnego, z jasno określonym zbiorem założeń i abstrakcyjnych twierdzeń podstawowych o najwyższym stopniu ogólności, z których wyprowadza się twierdzenia niższego rzędu" (Manterys, Mucha 2009, XIII) przy ważkim dopowiedzeniu, że poczynione ustalenia, wiedza będą przydatne dla praktyki, dostarczą bowiem „uogólnionych i usystematyzowanych informacji o przebiegach procesów edukacyjnych, wyjaśniających te procesy i mówiących o sposobach ich organizowania i realizacji” (Muszyński 2004, 92). Jak łatwo zauważyć, istotę teorii stanowi ogólność sądów, uchwycenie zależności między faktami oraz otwarcie na zjawiska jeszcze nieznane. Otóż warto zaakcentować, że przez teorię rozumie się „wyłącznie takie sądy ogólne mówiące o ich występowaniu, które mogą służyć za przesłanki dla dwojakiego rodzaju wniosków: po pierwsze, wyjaśniających dane zjawisko, a więc stanowiących odpowiedź na pytanie, dlaczego ono zachodzi oraz, po wtóre, pozwalających przewidzieć dane zjawisko, a więc stanowiących odpowiedź na pytanie o warunki, w jakich ono występuje" (Muszyński 2004, 96). Do rozwiązania problemu, co jest nieustannie potrzebne pedagogice, odwołuje się B. Śliwerski, akcentując, że istotę stanowi „generowanie podejść syntetycznych, które wyprowadzą teorie wychowania i kształcenia poza granice i ograniczenia cząstkowych paradygmatów i ich rozmaitych autorskich wariantów, także irracjonalnych czy pseudonaukowych" (Śliwerski 2017, 57).

Samoświadomość pedagoga jako teoretyka i badacza nakazuje poszukiwać zbioru narzędzi niezbędnych do określenia badanego zakresu zjawisk rzeczywistości edukacyjnej w ramach obranej tradycji teoretycznej tak, że teoria staje się instrumentarium intelektualnego zorientowania jego programu badawczego dookreślanego pod kątem praktyki edukacyjnej i jej potrzeb. Nie bez racji należy uznać, iż „teoria odnosi się w szczególny sposób do rzeczy- 
wistości, w taki mianowicie, że tylko z rzeczywistości może zostać wyprowadzona, rzeczywistość opisuje i w konfrontacji z rzeczywistością się sprawdza" (Muszyński 2004, 96). Tym samym, a może należałoby powiedzieć, co więcej, uprawianie naukowej pedagogiki, spełniającej jednocześnie wymóg teoretycznego charakteru wiedzy i praktycznego jej zastosowania, odbywa się na drodze badań empirycznych. Można rzec - przywołując „szkołę” myślenia H. Muszyńskiego, że teoria właśnie z empirii wyrasta. Ponadto poglądy tego badacza na temat modeli teorii pedagogicznych na użytek praktyki kierują uwagę na teorie wyjaśniające i teorie prakseologiczne. Myśl pedagogiczna H. Muszyńskiego wzbogacona refleksją. Meinrda Perrez i Jeana-Luca Patry, rzuca dodatkowe światło zarówno na przydatność wiedzy teoretycznej dla praktyki, jak i fakt jej ustalania na drodze empirii. Teorie wyjaśniające „obejmują twierdzenia o zależnościach (deterministycznych lub probabilistycznych), jakie występują między zmiennymi” (Muszyński 2004, 103-104), natomiast teorie prakseologiczne - „wiedzę technologiczną, obejmującą wypowiedzi o tym, za pomocą jakich działań lub procedur możliwe jest osiąganie założonych efektów, a więc celów" (Muszyński 2004, 104). To w istocie omawiany przez B. Śliwerskiego - za Radimem Paloušem - podział na fundamentalny i praktyczny sposób zajmowania się teorią wychowania (Śliwerski 2017, 60).

W rozważaniach nad pedagogiką jako nauką uwaga przeto skierowana jest na twierdzenia teoretyczne o zależnościach między zmiennymi, które stanowią składową zarówno wiedzy monologicznej, jak i technologicznej, ale - jak akcentuje H. Muszyński - zależności te zasadniczo różnią się od siebie. Autor podkreśla przede wszystkim trzy aspekty: „po pierwsze, zależności nomologiczne stanowią swoistą teoretyczną podstawę dla tych drugich: naukowe opracowanie technologii celowego przekształcania rzeczywistości wymaga uprzedniego wyjaśnienia obejmujących ją zjawisk. Toteż niepodobna budować wiedzy technologicznej w oderwaniu od wiedzy nomologicznej (wyjaśniającej) ani też niezależnie od niej lub poza nią. Po drugie, twierdzenia nomologiczne podlegają procedurom weryfikacyjnym, natomiast technologiczne - optymalizacyjnym: w przypadku pierwszych znajduje zastosowanie kryterium prawdziwości, natomiast wobec drugich - kryterium efektywności. Po trzecie wreszcie, twierdzenia technologiczne zawsze znajdą swoje uzasadnienie w twierdzeniach nomologicznych, gdyż są szczególnym przypadkiem tych drugich" (Muszyński 2004, 104). Chodzi wszakże o to, że najistotniejszym narzędziem realizacji celów poznawczych w pedagogice jest „dobra teoria” pedagogiczna (złożona z wiedzy nomologicznej i technologicznej), skupiona na opisie i eksplantacji zjawisk i procesów wychowania, edukacji oraz użyteczna dla praktyki, a także adekwatna dla potrzeb z tej praktyki wynikających. Z tego powodu, można - za B. Śliwerskim - traktując pedagogikę jako gałąź wiedzy o kształceniu i wychowaniu, uznać, że „współcześnie naukowy 
opis rzeczywistości wychowawczej [...], opiera się na przesłankach intersubiektywnie komunikowanych i sprawdzalnych oraz na logice, prowadząc do sformułowania między innymi sądów opisowych, wyjaśniających, normatywnych, prakseologicznych lub prognostycznych, które mają charakter probabilistyczny" (Śliwerski 2017, 63). Przyznać należy, że powyższe konstatacje czynią pedagogikę równorzędną innym naukom społecznym i akcentują dodatkową wartość i osobliwość budowania teorii w pedagogice, a mianowicie: teoria naukowa budowana na gruncie pedagogiki nie ogranicza się do opisu i eksplantacji zjawisk i procesów, lecz zwrócona jest (powinna być) ku wypełnianiu przez tę dyscyplinę naukową jej podstawowych funkcji: antycypacji zdarzeń, ich eksplantacji, wywieraniu wypływu na ich przebieg oraz użyteczności dla praktyki (Muszyński 2004, 97; Cybal-Michalska 2021, 99-101).

\section{Wnioski końcowe}

Ważką implikacją w kontekście podjętych rozważań nad aktywnością teoretyzowania w pedagogice, nad pedagogiką jako dyscypliną naukową jest uwydatnienie faktu, że w obrębie tej dyscypliny w zakresie nauk społecznych i humanistycznych uprawnione i pożądane jest nie tylko poszukiwanie odpowiedzi na pytanie: Jak jest? (dostarczające wiedzy wyjaśniającej przebieg procesów i zdarzeń edukacyjnych, społeczno-edukacyjnych), ale również - Jak może być?, czy też nawet: Jak powinno być? Należy stwierdzić, biorąc pod uwagę przywołane we wcześniejszym fragmencie artykułu rozstrzygnięcia B. Misztala i H. Muszyńskiego, że w refleksji pedagogicznej nad historycznie przeobrażającą się rzeczywistością społeczno-edukacyjną na szczególną uwagę zasługuje z pewnością wymiar czasu oraz przestrzeni, ale również - co należy dopowiedzieć - wymiar efektywności, a więc konceptualizacja, budowanie wiedzy teoretycznej z wyraźnie ,praktycznym” jej wycieniowaniem - wiedzy mającej zastosowalność w praktycznych działaniach edukacyjnych pod kątem potrzeb edukacyjnej praktyki i osiągnięcia określonych celów edukacyjnych. To właśnie w obrębie pedagogiki jako nauki o wychowaniu, zjawiskach i procesach edukacyjnych wyróżnione wymiary nie powinny być ignorowane, to one bowiem świadczą o rozwoju i żywotności tej dyscypliny, jej tożsamości, a także powadze, odpowiedzialności i znaczeniu.

Ważne, że kiedy zastanawiamy się współcześnie, w doświadczeniu zmienności i ambiwalencji globalizującego się świata, wielości możliwości, jak pogodzić trwałe wartości i zmienny świat ${ }^{6}$, to z pomocą może przyjść właśnie

\footnotetext{
${ }^{6}$ Tak postawione pytane wygłosiła na pierwszym inauguracyjnym posiedzeniu Zespołu ds. Kultury i Edukacji Międzykulturowej prof. Irena Wojnar.
} 
wyobraźnia pedagogiczna, która traktuje edukację jako przestrzeń nie tylko transmisji kultury, ale przede wszystkim transformacji kultury. Konsekwencją tego stanu rzeczy niech będzie stwierdzenie, że istnieje alternatywa dla świata, w którym partycypujemy, i można zmieniać jakość ludzkiego życia we współczesnym obrazie kultury, i to właśnie pedagodzy mają ten przywilej jej urzeczywistniania. Pamiętać przy tym należy, że odbywa się to w warunkach wielości, sfragmentaryzowania i heterogeniczności, a to oznacza, że „wszystkie nauki humanistyczne i społeczne są konfrontowane z pluralizmem idei, teorii, ideologii i filozofii wychowania czy kształcenia" (Śliwerski 2017, 117). Myśl edukacyjna (dobra teoria pedagogiczna) wczoraj i dziś jest osią narracji przeobrażającej się rzeczywistości społecznej.

\section{EDUCATIONAL THOUGHT - ABOUT THE SERIOUSNESS OF THE THEORETICAL SOCIO-PEDAGOGICAL FINDINGS}

\section{SUMMARY}

The author in the article poses questions regarding pedagogy as a research discipline turned towards the construction of theory - theoretical knowledge explaining the processes of upbringing. She emphasizes the fact that from the theoretical-cognitive perspective, cognitive practice and expectations of the exploratory value of statements formulated by the theory refer to the possibility of theoretical generalization and classification of the social world. Also they offer translation of theoretical theses into the ground of empirical cognition in order to verify them, as well as to explain phenomena through the identification of causal mechanisms and revealed processes. The exploratory capacity of a theory is determined by recognizing the size of the scope of reality to which the theory applies. Making pedagogy equal to other social sciences, it is impossible not to emphasize the additional value and peculiarity of theory construction in pedagogy, namely: the research theory constructed on the ground of pedagogy is not limited to the description and explanation of phenomena and processes, but it is directed towards anticipation of events, influence on their course and their usefulness for practice.

Keywords: research theory, explanatory capacity of a theory, pedagogy as a science, theoretical pedagogy

Słowa kluczowe: teoria naukowa, zdolność eksplanacyjna teorii, pedagogika jako nauka, pedagogika teoretyczna 


\section{BIBLIOGRAFIA}

Barker, Chris. 1999. Television, Globalization and Cultural Identities. Philadelphia: Open University Press.

Bauman, Zygmunt. 2000. Globalizacja. Warszawa: Państwowy Instytut Wydawniczy.

Cybal-Michalska, Agnieszka. 2006. Tożsamość młodzieży w perspektywie globalnego świata. Poznań: Wydawnictwo UAM.

Cybal-Michalska, Agnieszka. 2013. Młodzież akademicka a kariera zawodowa. Kraków: Wydawnictwo Impuls.

Cybal-Michalska, Agnieszka. 2001. „Oddech myśli” jako uobecnianie przeszłości. W: Dziedzictwo pedagogiczne dla przyszłości. Debata wokót „Oddechu Myśli” Bogdana Nawroczyńskiego, red. Anna Babicka-Wirkus, Monika Jaworska-Witkowska, Dariusz Kubinowski, 91-103. Kraków: Wydawnictwo Impuls.

Golka, Marian. 1999. Cywilizacja. Europa. Globalizacja. Poznań: Wydawnictwo Fundacji Humaniora.

Golka, Marian. 2002. Kultura w przestrzeni globalnej. W: Społeczne problemy globalizacji, red. Zbigniew Blok, 77-90. Poznań: Wydawnictwo UAM.

Kahn, Joel Simmons. 1995. Culture, Multiculture, Postculture. London: Sage Publications.

Kempny, Marian. 1998. Globalizacja. W: Encyklopedia socjologii. Tom I, red. Andrzej Kojder, 241245. Warszawa: Wydawnictwo Oficyna Naukowa.

Kwieciński, Zbigniew. 2004. Problem pedagogii nurtów głównych i pobocznych. W: Uniwersytet. Społeczeństwo. Edukacja, red. Wiesław Ambrozik, Kazimierz Przyszczypkowski, 29-42. Poznań: Wydawnictwo UAM.

Lewowicki, Tadeusz. 2004. Wystąpienie. W: Tadeusz Lewowicki. Doctor Honoris Causa Universitatis Opoliensis, 43-51. Opole: Wydawnictwo Uniwersytetu Opolskiego.

Liberska, Barbara. 2002. Współczesne procesy globalizacji gospodarki światowej. W: Globalizacja. Mechanizmy $i$ wyzwania, red. Barbara Liberska, 17-37. Warszawa: Polskie Wydawnictwo Ekonomiczne.

Mały słownik języka polskiego, red. Elżbieta Sobol. 2000. Warszawa: Wydawnictwo PWN.

Manterys, Aleksandra i Janusz Mucha. 2009. Nowe perspektywy teorii socjologicznej. Punkt widzenia 2009 r. W: Nowe perspektywy teorii socjologicznej, red. Aleksandra Manterys, Janusz Mucha, VII-XXVII. Kraków: Zakład Wydawniczy Nomos.

Marshall, Gordon. 2005. Stownik socjologii i nauk społecznych. Warszawa: Wydawnictwo Naukowe PWN.

Martin, Hans-Peter i Harald Schumann. 1999. Pułapka globalizacji. Wrocław: Wydawnictwo Dolnośląskie.

Misztal, Bronisław. 2000. Teoria socjologiczna a praktyka społeczna. Wydawnictwo Universitas.

Muszyński, Heliodor. 2004. Teoria w pedagogice. W: Uniwersytet. Społeczeństwo. Edukacja, red. Wiesław Ambrozik, Kazimierz Przyszczypkowski, 89-106. Poznań: Wydawnictwo UAM.

Robertson, Roland. 1992. Globalization. Social Theory and Global Culture. London: SAGE Publications.

Robertson, Roland. 1985. The Relativization of Societies: Modern Religion and Globalization. W: Cults, Culture and the Law, red. Thomas Robbins, William C. Shepherd, James McBride, 31-42. Chico: Scholars Press.

Scott, John and Gordon Marshal. 2009. Oxford Dictionary of Sociology. Oxford: Oxford University Press.

Starosta, Piotr. 2000. Globalizacja i nowy komunitaryzm. Kultura i Społeczeństwo, 3, 47-68.

Sztompka, Piotr. 2002. Socjologia. Kraków: Wydawnictwo ZNAK.

Śliwerski, Bogusław. 2007. Pedagogika ogólna w ponowoczesnym świecie. W: Profesor Bogusław Śliwerski. Doctor Honoris Causa KUL, 51-119. Lublin: Wydawnictwo KUL. 
Stownik współczesnego języka polskiego tom II, red. Elżbieta Wierzbicka. 2008. Warszawa: Wydawnictwo Reader's Digest.

Ziółkowski, Marek. 2006. Teoria socjologiczna początku XXI wieku. W: Współczesne teorie socjologiczne. Tom 1, opr. Aleksandra Jasińska-Kania, Lech Nijakowski, Jerzy Szacki, Marek Ziółkowski, 15-31. Warszawa: Wydawnictwo Naukowe Scholar.

Ziółkowski, Marek. 2006. Wstęp. Teoria strukturalistycznego konstruktywizmu i teoria strukturacji. W: Wspótczesne teorie socjologiczne. Tom 2, opr. Aleksandra Jasińska-Kania, Lech Nijakowski, Jerzy Szacki, Marek Ziółkowski, 631-633. Warszawa: Wydawnictwo Naukowe Scholar.

Agnieszka Cybal-Michalska - pedagog, specjalistka w zakresie pedagogiki ogólnej i socjologii edukacji, profesor nauk społecznych, profesor zwyczajny Uniwersytetu im. Adama Mickiewicza w Poznaniu, dziekan Wydziału Studiów Edukacyjnych tej uczelni. 